\title{
علم الرياضيات الصعوبات والتحديات والتوجهات الحديثة في دراسة الرياضيات
}

جهاد كاظم 3صر

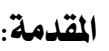

و الرياضيات تعمل على اكساب الفرد

ان الرياضيات هى علم مــن العلـــوم

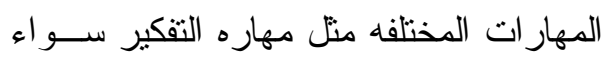

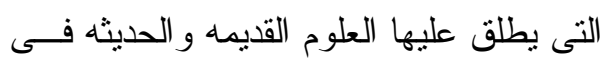
كان التفكير مجرد او تفكير نقدى أو مكانى

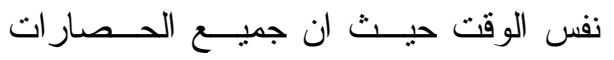

ـ كما ان لها القدره على تتميه الابداع وزياده

و الثُعوب لا نستطيع الاستغناء عنها كما انها

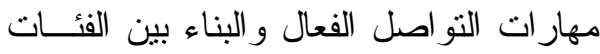

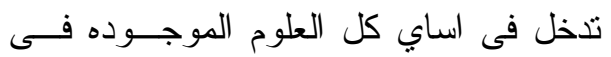
المختلفه من الأفر اد. - مهن

الوقت الحاضر سواء الكيمياء أو الاحياء أو لودئ

وللرياضيات اهميه كبرى ايضنا فـى هـ الهي

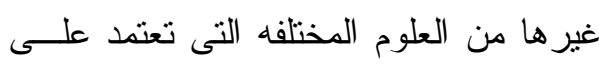
مساعده الافراد على اتخاذ القرار ات السليمه القياسات و المقادير و الارقام و المعادلات. (')

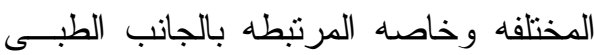
وبما ان علم الرياضيات هو الاساس مما يجعلها عامل مساعد فى تحسين وزيــاده

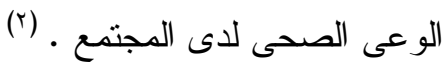

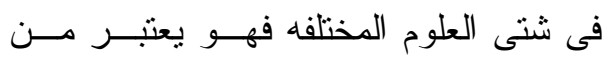

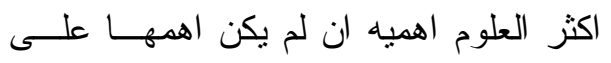
اما على الجانب التعليمى فان دراسه

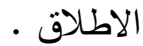

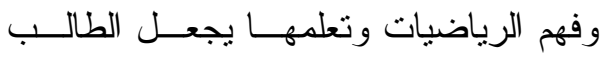
كما ان علم الرياضيات يعمل علــى

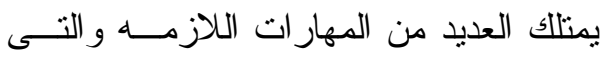

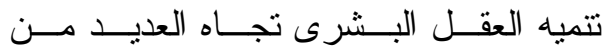
تساعده فى حياته المستقليه و الوظيفيه كمــــا

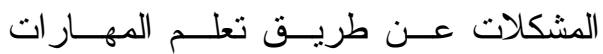
تساعده فى شتى مجالات حياته اليوميه . الاساسيه للرياضيات فينظر الــى المــشكله لذا وجب الاهتمام بتوضيح ماهيه الرياضيات

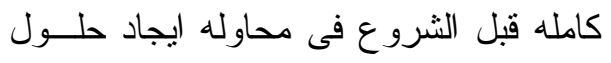

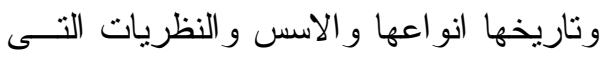


طريقه علم الاعداد من طرح وقـسمه

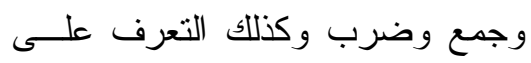

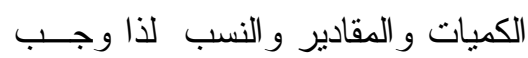

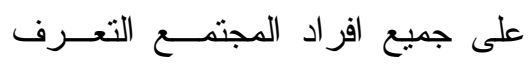
عليها حتى لا تصبح عقبه فى تعاملاته

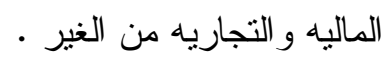
الاهداف الخاصه بالطالب :

1- توضيح اهمية الرياضيات كعلم يستخدم

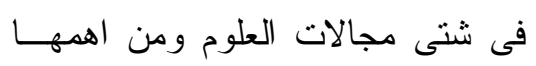

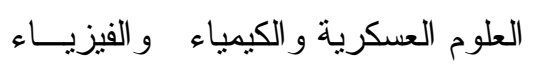
و العلوم الاجتماعية والمعاملات الماليه و الاقتصادية . ولعوم الاجنماع r- المساعده في تكوين بعض الاتجاهـات

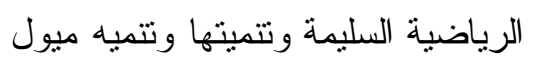
الطلبه نحو تذوق الرياضيات للمساعده فى تكوين اجيال مبتكره وبار عه .

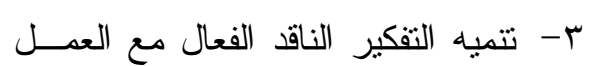

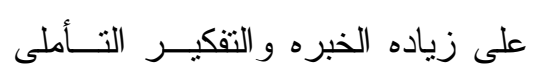
و التقكير التحليلى.

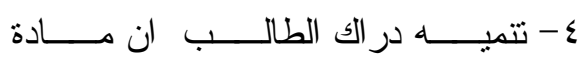
الرياضيات مادة حية ومتجددة يمكـن

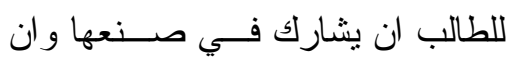
يبتكر بر اهين جديده لها. 0- المساعده على تكوين بعض الإتجاهات

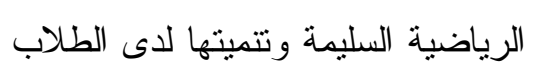
مع تكوين البصيره الرياضيه لديهم.
تقوم عليها حتى يكون ذلك حافز للطلاب فى المر احل التعليميه المختلفه للاهتهــام بمــاده

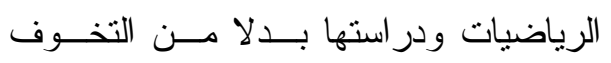

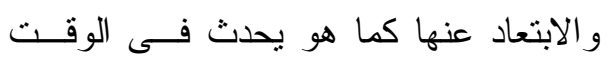

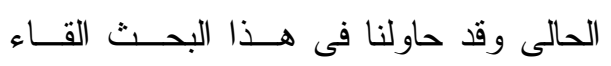
الضوء بنبذه مختصره عن الرياضيات بشكل هات هون

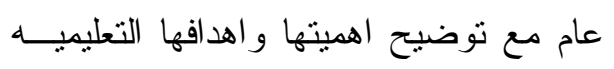

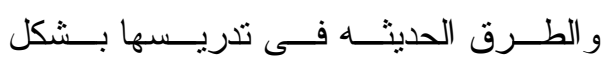
خاص. (')

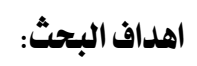
الاهد|ف العامه : 1- ان در اسه الرياضيات يعمل على فهـــ الرهم

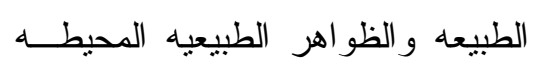
بنا منل الجاذبيه الارضــيه وحهـساب المد و الجزر و الليل و النهــار ودوران الثمس مما يساعد على التعرف علــى ولى ولى ولى حقيقه الكون و اسر اره. r- بما ان الرياضيات هى علم الارقام فان

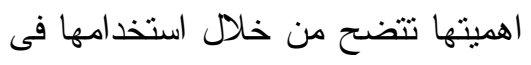

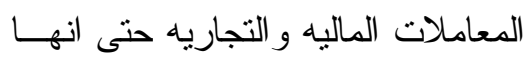

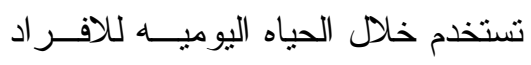

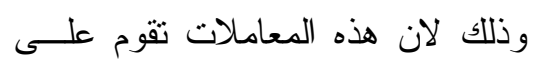

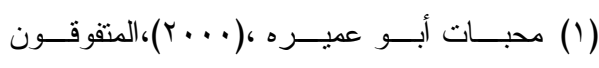

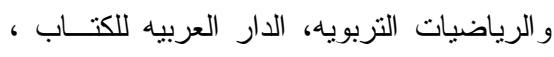
القاهره. 


$$
\begin{aligned}
& \text { و اتخاذ القرارات السليمه التــى يقــوم } \\
& \text { 7- تتميه مهار ات الطلاب على اســتخدام }
\end{aligned}
$$

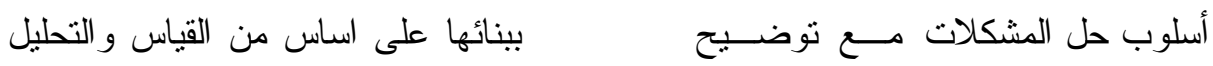

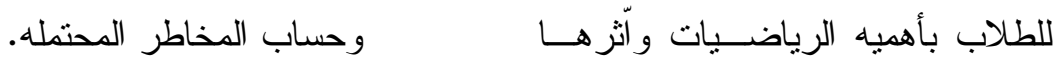

$$
\begin{aligned}
& \text { الفعال فى تطور الحضار ات المختلفه . مصطلحات البحث : }
\end{aligned}
$$

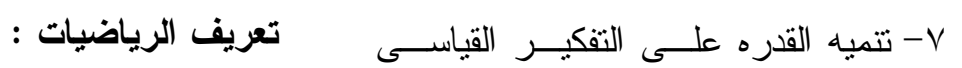

$$
\begin{aligned}
& \text { ان الرياضيات هى علم يتتاول العديد }
\end{aligned}
$$

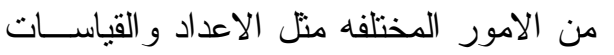

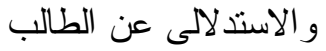

$$
\begin{aligned}
& \text { اهميه البحث : }
\end{aligned}
$$

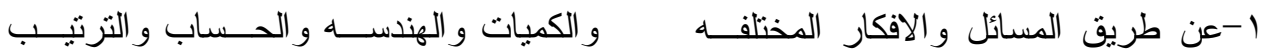

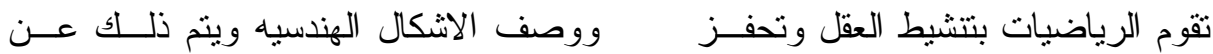

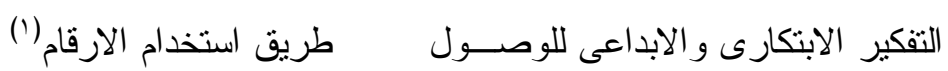

$$
\begin{aligned}
& \text { هي العلم الذي ينطوي على دراســه }
\end{aligned}
$$

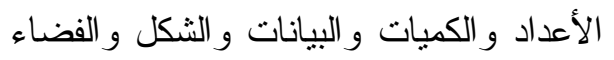

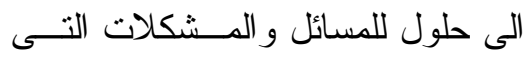

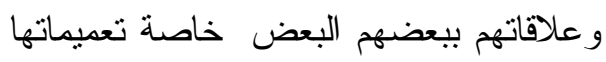

$$
\begin{aligned}
& \text { وتجريدها وتطبيقها على المو اقف في العـالم } \\
& \text { الحقيقي. (r) } \\
& \text { تعريف صعوبات تعلم الرياضيات } \\
& \text { عدم القدره على التعامل مع الأرقــام } \\
& \text { و العمليات الحسابية او القـــــين الرياضـــية } \\
& \text { بشكل صحيح مع وجود مشكلات في دراسة }
\end{aligned}
$$

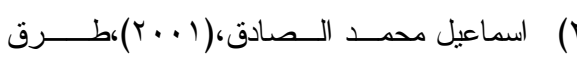

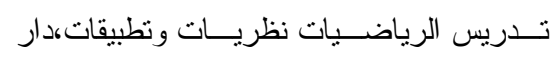

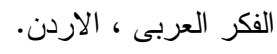




$$
\text { - الحساب }
$$

ويتضمن فرع الحسـساب و هـــويعتبر

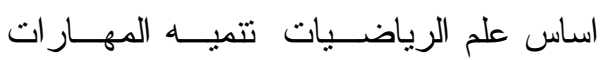

الاساسيه فى الرياضيات ودر اســة الأعـــداد

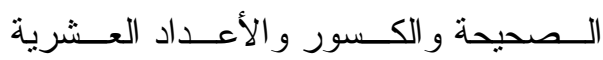

و ومليات الجمع و الطرح و الضرب و والقسمة ولن

و التعرف على الكميات و المقاييس .

$$
\text { r }
$$

يتضمن القيام بحل المعسـادلات التـى

تحنوي على رموز منل س وصكما يتضمن بلن

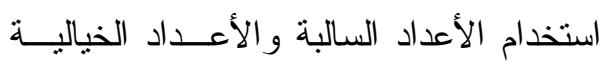

والجذور التربيعية للأعداد السالبة وذلك فـى الاعى

العمليات الجبريه.

$$
\text { r- الرناسه : }
$$

ومن خلال الهندسه نستطيع دراســـه

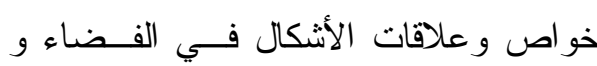

المربعات و الدو ائر و المستطيلات. (r)

$$
\text { ـ - الهندسة الفراغية }
$$

وهى علــم در اســـة الأشــكال ذات

الأبعاد الثلاثة متل المكعب و الكرة .

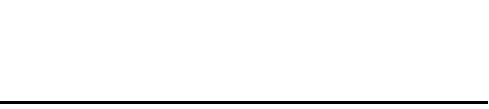

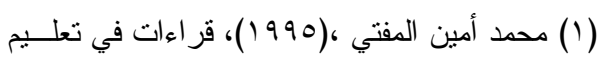

الرياضيات ، مكتبة الأنجلو المصرية ، القاهرة ..
الكسور و الجبر و الهندسة والاحصاء و غيرها

(') من فروع الرياضيات

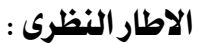

تعد الرياضيات مادة در اســـية دقيةـــة

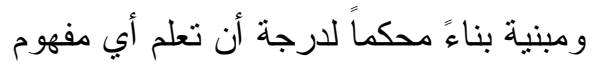

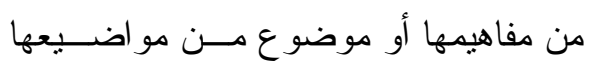

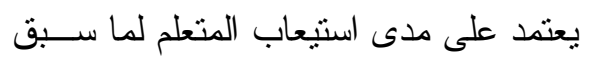
در استه من مفاهيم أو موصو عات ، ويتطلب

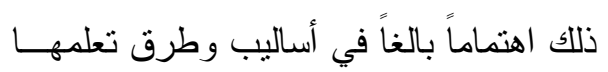
للوصول للهدف المطلوب. (؟) اولا : فروع الرياضيات :

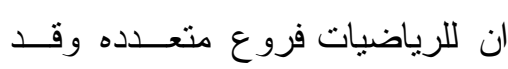

تختلف هذه الفروع فــي نوعيــة المسـائل

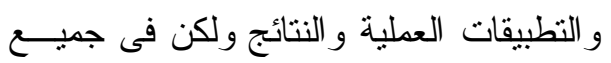

مجالات الرياضه نـستخدم نفـس المفــاهيم

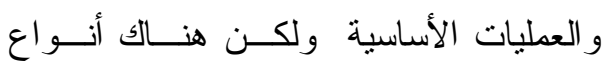

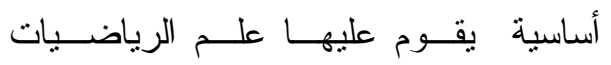
وهى :

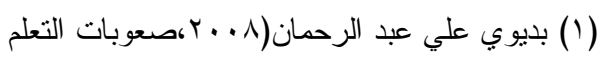

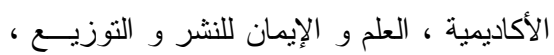

$$
\text { الإسكندرية. }
$$

(1) رشدي راثد،(ع . . ب)، تاريخ الرياضيات العربية

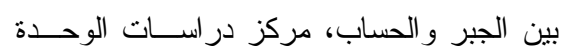

العربية 
الحكوميه و العلوم الانسانيه و الاجتماعيه وفى

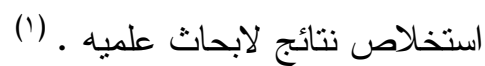
ثنانيا : معوقـات وصــوبات تعلــم

الرياضياتان الصعوبات التى تو اجها تدريس

وفهم وتعلم الرياضــيات متعــدده وكثيـــره

وتتشمل العديد من الجوانب التى من شأنها ان

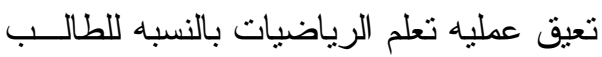

$$
\text { ونذكر منها : }
$$

اولا : معوقات تتعلق بالطالب نفسه مثل

$$
1 \text { - المشكلات الحسيه والاجتماعيه }
$$

وهى تمنّل احدى مشكلات المجتمــع

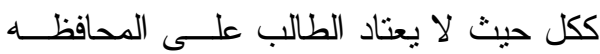

على النظام داخل الفصل الدراسى مع احداث الفوضى و عدم احتر ام المبادىء التى تقــوم عليها العمليه التعليميه لعدم اعتياده على ذلك من البيئه التى نشأ بها وكذلك عدم التعــاون

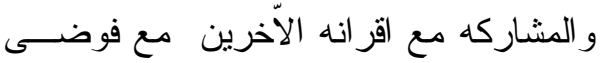
الاجابه على الاسئله وشغل الحصه بأســئله

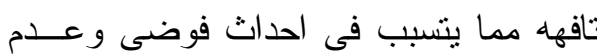

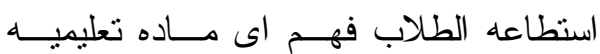

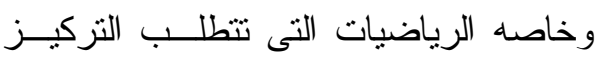

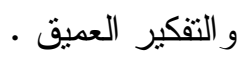

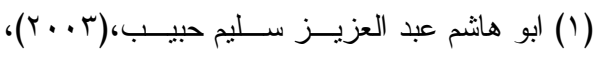
تدريس الرياضيات ، مكتبه النهضه المـصريه

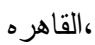

ه - الهندسة التحليلية

و هى تقوم بالربط بين الجبر و الهندسة

بحيث نستطيع من خلالها القيام بالتعبير عن منحنبات عدة بمعادلات جبرية.

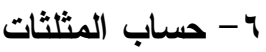

احد افرع الرياضيات التى تقوم علــى حساب العلاقة بين أضلاع وزو ايا المنلـــث و على الأخص المنلث قائم الزاوية ويــستخدم

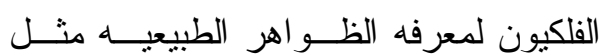

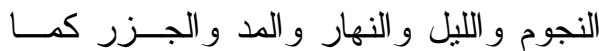
يستخدمه البحارة و المساحون و المهندســون و الفيز ائيون لمعرفه وتحليل خو اص الــضوء و الماء و السؤ ال المختلفه. V - حساب التفاضل و التكامل والتحليل يتضمن القيام بلدر اسه العمليــات مــع كميات متتاهية الصغر أو متغيره عن طريق ليقن

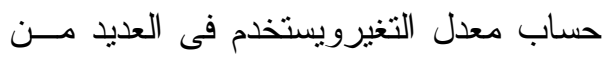
العلوم منل الفيزياء و الهندسه و الجغر افيا. 1- الاحتمالات و الإحصاء الاحتمالات هـى در اســـه احتماليــه

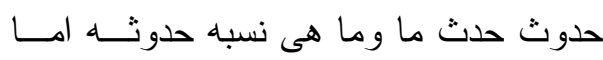
الاحصاء فهى عمليه جمع للبيانات وتصنيفها

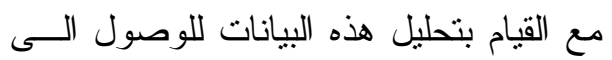

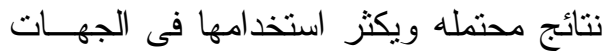


الرياضيات حيث ان الثروع فى البدء بالتدريس مباشره مع الثعور الـسائد بالخوف من الرياضيات عند الطلاب بؤدى الى عدم الفهم.

r- عدم استطاعه المعلم توصيل المعلومه الرياضيه للطالب بشكل صحيح وذلك

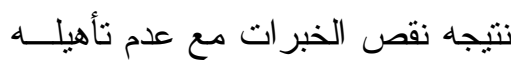

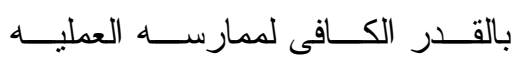

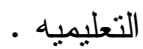
r- عدم قيام المعلـــم بمر اعـــاه الفــروق الفرديه بين الطلاب عند القيام بشرح الدرس المقرر وذلك نتيجـــه افتقـــاره للخبره الكافيه التى تؤهله لمر اعاه ذلك أو نتيجه عدم الرغبه فى بذل مجهود اكثر لتعليم الطلاب اصحاب الذكاءات المنخفضه عن اقر انهم.

ثالثا : معوقات تتعلق بالنظام التعليمى 1- تحميل المعلم الكثير من الاعباء:

وذلك عن طريق القيام بتكليف معلــم الرياضيات بالكثير من الاعباء منل الاتشر اف

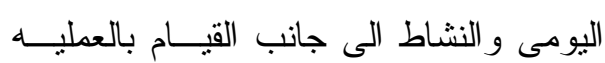

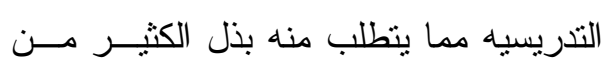
الجهذ الذى يسبب له الارهاق و عدم التزكيز

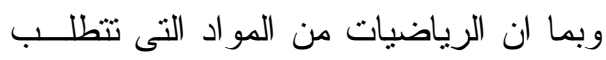
التزكيز و التفكير و الانتباه فلن بسنطيع المعلم

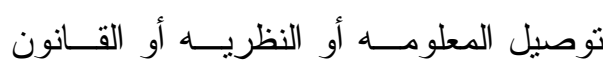
الرياضى للطالب بشكل صحيح . r - المشكلات العقليه و النفعاليه

وهى تثمل الفــروق الفرديـــهـ بــين

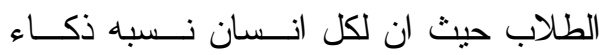
وتركيز و انتباه تختلف عن الاخرين لذا فــان

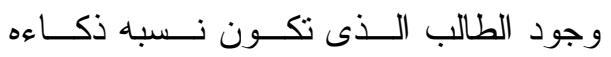
منخفضه عن اقر انه وكذلك شرود الذهن لدى

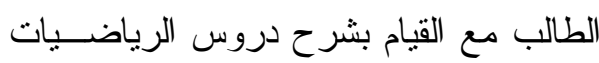

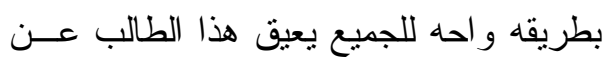

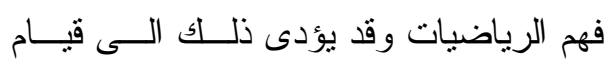
الطالب بما يسمى الانسحاب أو الصمت عند فئدئ

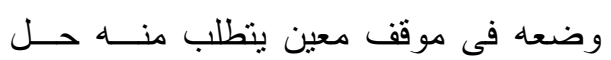
مسأله رياضيه لا يعرفها. (1) r- نقص الدافع لتعلم الرياضيات ويأتى ذلك نتيجه احساس الطالب بعدم جدوى دراسه الرياضيات وعـدم اهميتهـــا نتيجه بعض الافكار الخاطئه التى يـستمدها من البيئه الخارجيه المحيطه به. ثانيا : معوقات تتعلق بالمعلمين

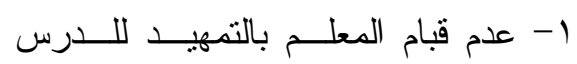

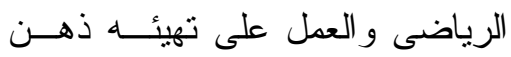

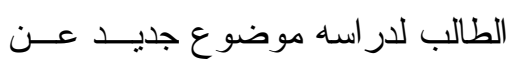

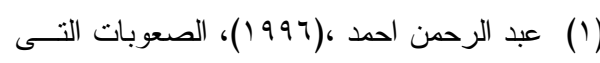

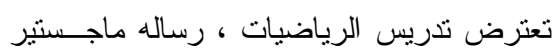
غير منثوره ، كليه التربيـــه ، جامعـــه بنهـا. 
زيادة القدرة على تعلم المـسائل الرياضــية وحلها، ومن أهم هذه الطرق ما بلي: طريقة التعلم الإيجابي تعتمد هذه الطريقــة علــى تـشَيع

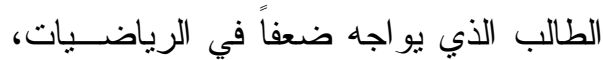

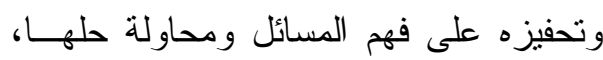

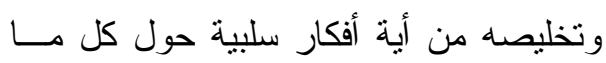
يتعلق في الرياضيات. يتم بهذه الطريقة تكليف الطالب بالقيام بالنشاط التعليمي الرياضـــي بنفـسه حتــى يتخلص من حاجز الحوف والقلق الذي ينتابه

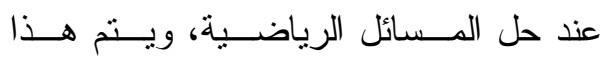

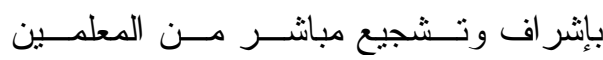

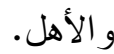

$$
\text { طريقة التدريس المباشر }
$$

تربط هذه الطريقة بين الطريقة التـي

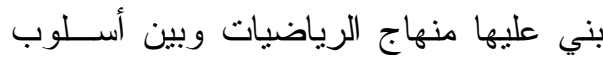
مدرس الرياضيات وطريقتـــه فـــي إيـــال المعلومة حيث يقوم المدرس بشرح المسائل الرياضيه مع الاعاده و التكر ار و هذه الطريقه

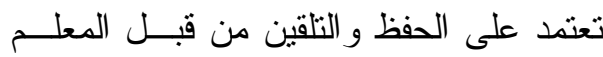

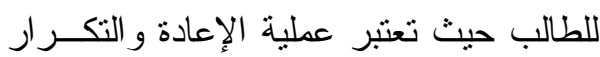

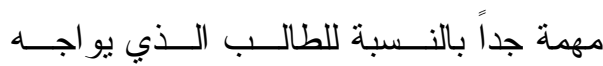
صعوبة في التعلم.

\section{طريقة التعليم الجهزي المسموع}

و هذه الطريقة يشترك فيهــا المعلـــم و الطالب ويقوم فيها معلم الرياضيات برفـــع

$$
\text { r- عدم مناسبه المقرر الدراسى: }
$$

حيث ان المقررات الدراسيه فى ماده

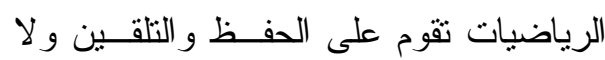
تقوم على اعطاء الحريه للطالــب للابتــــــار و الابداع ومع طول المقرر الدر اسى وعـــدم مناسبته كما ان بعض التمــارين و المـسـائل الموجوده داخل كتب الرياضيات معقده وغير لير

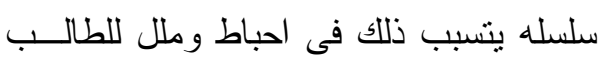
مع عدم الفهم و التفكير و التزكيز .

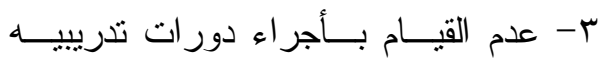
لمعلمى الرياضيات لتعـريفهم بأحسدث الطرق فى تدريس الرياضيات مع التنبيه بممارسه هذه الطرق و الاساليب الحديثه بعد فهمها و اتقانها .

ع- عدم توفير المواد و الأجهــزة التعليميــة

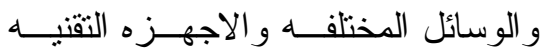
الحديثه و التى يحتاجها معلم الرياضيات فى العمليه التعليميه. (')

طرق مواجهه صعوبات تعلم الرياضيات : يتم عــلاج صـــوبات الـتـعلم فـي الرياضيات باتخاذ عــدداً مــن الإجــر اءات

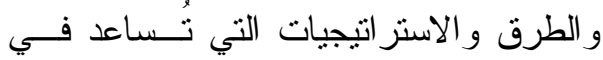

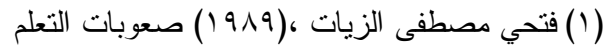
الألسس النظرية و التثخيصية و العلاجيــة "، دار النشر للجامعات، القاهرة. 
r- احدى الاساليب الفعاله فـى تـــــــ

الكثبر من الموضو عات الرياضية

r- يساعد على تتميه وتعزيز الكثير مـن

المفاهيم و المهار ات و المبادئ الرياضية

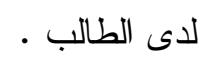

الأنشطة النى تنتخدم في تدريس المهــار ات

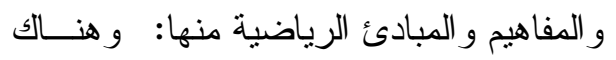

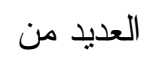

1- تـــسمية المهـــــار ات أو المفــــــيم أو

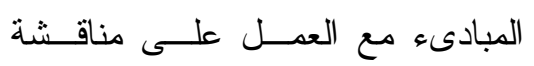
الأهداف مع الطلاب مع لـعاد

Y- تحديد ومناقثنة المهــار ات و المبــادئ

و القو انين الخاصه بالمو اضيع الجديـــــ

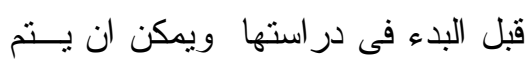

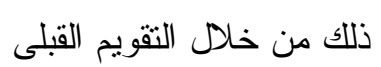

ب- تتمية المهار ات و المفاهيم و المبــادىء

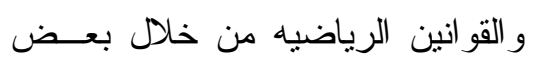

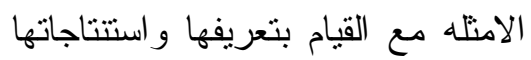

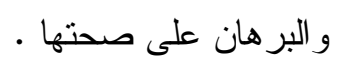

ع - تقديم التغذية الر اجعة الفورية من قبـــلـ

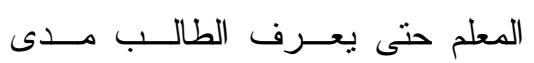

اكتسابه أو ضعفه في أداء المهــــــارة

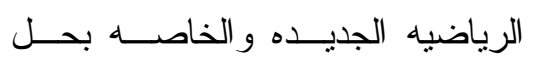

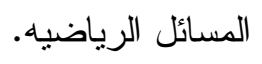

ه- اجر اء التقويم القبلى و البعـدى بــشكل لــن

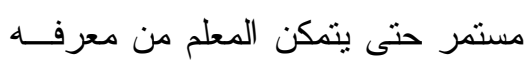

صوته أثناء الثرح وقر اءة المسألة بـصوت عالي ومسموع مع توضيح مفاهيم وقــــوانين المسألة و المطلوب منها وشر ح خطو ات الحل ثم يطلب المعلم من الطالب أن يقوم بنفـسه ونه

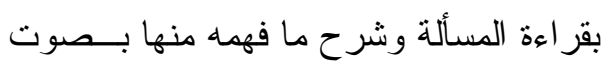

مسموع طريقة التعلم الفردي

تعتمد هذه الطريقة على الطالب نفسه

وتصميمه على فهم ودر اسه الرياضيات و هذ تلنئ يتطلب مجموعه من من القواعد الأساسـية ونية

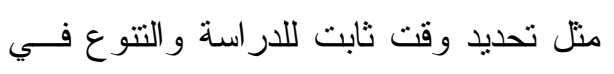
أسلوب الثر ح من قبل المعلم ومناقشته فــي وني

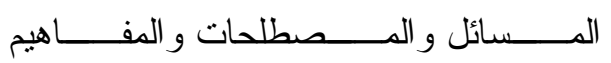

الرياضية. (1)

استراتيجيات تدريس الرياضيات:

اولا : استر اتيجيه العـرض المباشــر فـى

التعليم والتعلم السمات المميزة له له

1- يسيطر عليه المعلم ويقوم بالتحكم فـى

سير العمليه التدريسيه من خلال تقديم

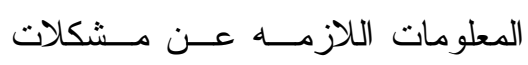

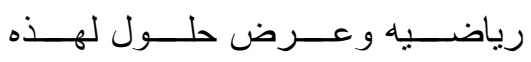

المشكلات.

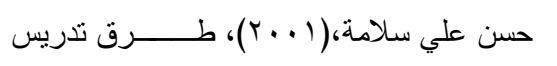

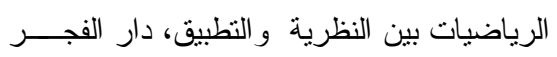

للنشر و التوزيع، القاهره. 


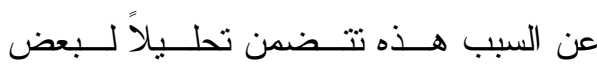

مـسـتوى تحــــيل الطالـــب ومـــدى

العمليات الرياضية. (')

فهمه للمفاهيم و المبـــادىء و القــــــن انين

ثالثاً : استر اتيجيه التعلم بالاكتشاف

و النظريات الرياضيه مما يساعد علـىى

هذه الطريقة تجعل الطالب يشترك فى

معرفه المشكلات التى يعــانى منهــا

عمليه التعلم ويعتبر هو العامل الاساسى بها

جيث انه يقوم بمر اقبه احدى الظو اهر وبيحث

ثانياً: استراتيجيه استخدام الالعاب في تعليم عن أمتلة ويجري تجارب ويجمــع بيانــات الرياضيات ويقوم بأخذ القرار المناسب حتــى يصل إلــي

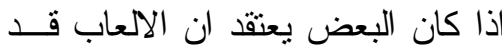
المعرفه وذلك باستخدام عقله و هــذا الــتعلم صنعت او صممت من اجل المتعة فقط فهذا يحدث نتيجه معالجه المعلومــات وتحليلهـــا يعتبر من الاخطاء الثائعه حيث انــه مــن و استخلاص النتائج منها حتى يصل الطالـبـ الممكن ان يمون للالعاب اهداف آخلاى منها

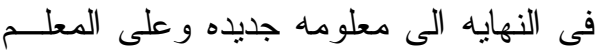
الأهداف المعرفيــة فالألعاب التــي تــصمم ستخدام عمليــات الاســتقر اء و الاســتنباط لأهداف تعلـــم معينــة وتــستخدم بطريقـة

صحيحة بوساطة المعلمين و الطلاب يمكن أن وذللك باستخدام المشاهده و الاستكمال عـن

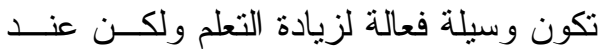
طريق مواقف معده مسبقا او عــن طريــق تحديد هذه الالعاب و استخدامها يجب مر اعاه المناقشات الحره التى تاخذ شــــل الــسؤال الاتى:

و الجو اب وتقيد هذه الطريقــــه الطالــبـ فــى

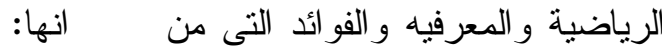
ا - حفظ الذاكرة عند الطالب وذللك مـن خلال تز ابط وتكامل المعرفة العلميـــة

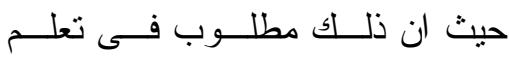
الرياضيات. الممكن ان تقدمها اللعبه فــى تتميـــه بعض المفاهيم و المبادىء الرياضــيه للطالب و هناك العاب مثل العــاب التخمــين لتعلم المفاهيم و المبادىء و العاب حل الالغاز و المتتاقضات و الالعاب الاسكتشافية أو البحث

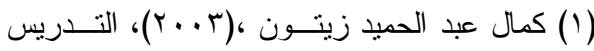

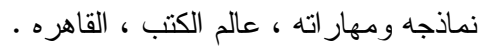




$$
\begin{aligned}
& \text { التحليليــة ويساعدهم في استخدام هذه } \\
& \text { القدر ات في مو اقف أخرى وئى } \\
& \text { r - هذا الاسلوب يساعد الطلاب على تعلم } \\
& \text { الحقائق و المهار ات و المفاهيم و المبادئ } \\
& \text { الرياضية }
\end{aligned}
$$

r- أن تعلم الطلاب حل المسائل له أهمية عظمى في تعلم الرياضيات بشكل عام

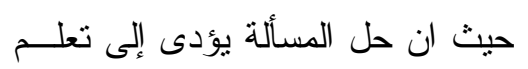

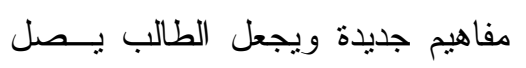

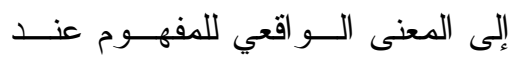

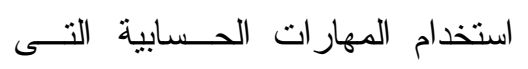

$$
\text { بتضمنها كان }
$$

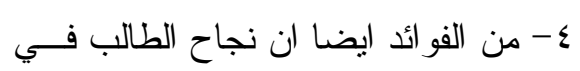

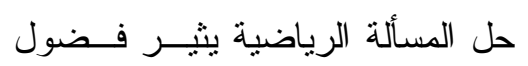

الفرد نحو حل مـسسائل آخرى. (')

خامسا: استر اتيجية التدريس الاستقرائي وهى تعنى الانتقال من الجزء إلى الكل وذاك من خلال تتبع الاجز اء و والتفاصيل والأمنتلة

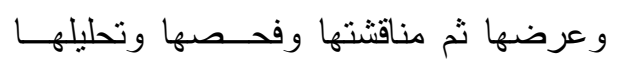

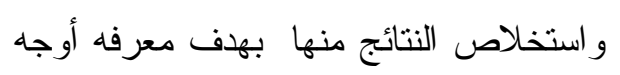
الشبه والاختلاف ثم الوصول إلى استتناجات ولها العديد من الفوائد ومنها:

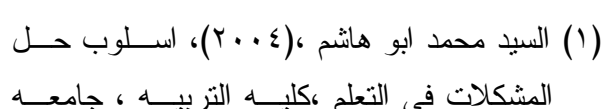
الزقازيق r- تتمى تزيد الدافعية و الطاقه العلميــــ

عند الطالب لتعلم الرياضيات وتعلمـــهـ طرق جديده فى الاكتشاف.

رابعا : استر اتيجيه التعلـيم والـتـعلم حـل لـل

المشكلات

وهو يعنى نطبيق المعارف والأساليب

و اســتر اتيجيات الحل السابق تعلمها من قبل ئل

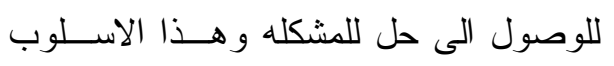

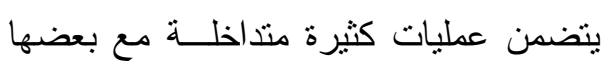

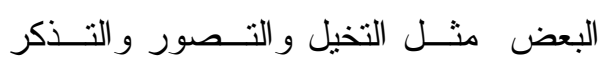
و التعميم و التحليل و التركيب ، و الاستتناجات

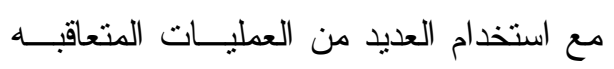

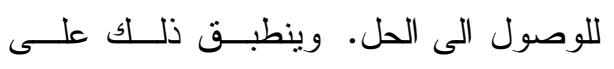

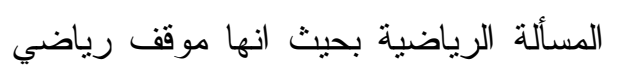

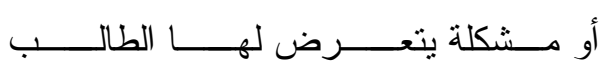

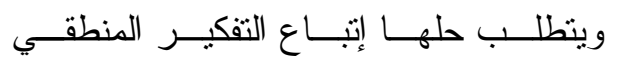

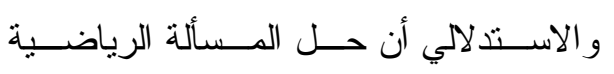

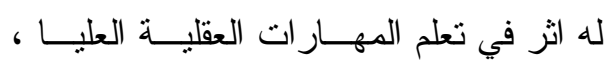

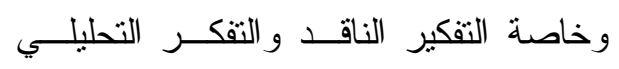

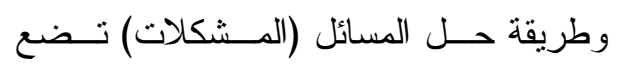
الطلبة في مو اقف تفكيريــة منــل التحليــل

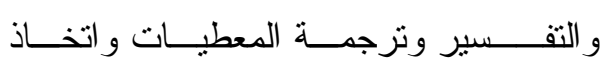
القر ار ات ولهزا الاسلوب العديد من الفوائد منها : ا- ان حل المشكلات الرياضــية يـسـاعد

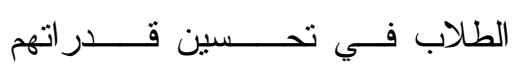


اصبح مــن الــضرورى و الهــام اســتخدام

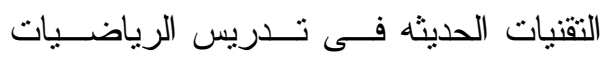

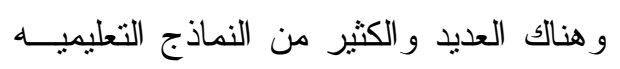

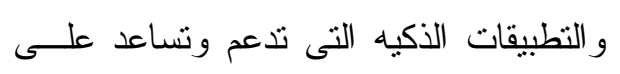

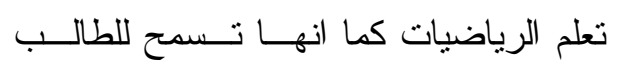

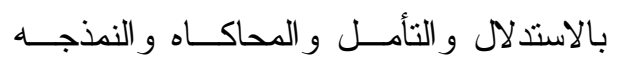

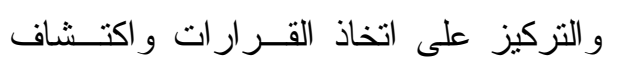
طرق جديده لحل المسائل الرياضيه ومن هذه

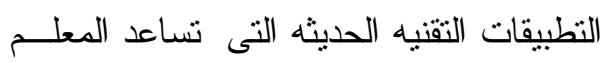

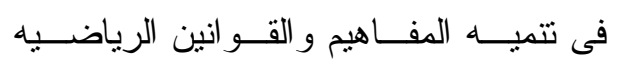

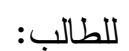

1- Pencil box ،Geometry

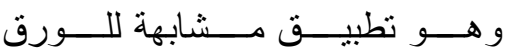

$$
\begin{aligned}
& \text { البياني لرسم الخطوط و الأشكال الهندسية. }
\end{aligned}
$$

2- Number frame ‘Number line ،Linear $\quad \mathrm{Eq}$ ،Fraction

Division ،Picturing

Ef،Measure ،Geoboard

$$
\text { تطبيق لتبسيط وتعلم وتعليم المفــاهيم }
$$

$$
\text { و الافكار الرياضية. }
$$

3- Make it ،Tiny Tap

$$
\text { و وتصميم الألعاب التفاعليه صــم خصيــصـا لبنـــاء }
$$

4- Popplet Lite ،Ledament

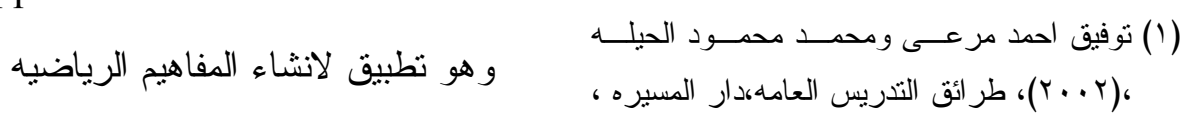

ا. احد الطرق الهامه المستخدمه فـى التعليم النشط r. ان الانتقال من البسيط إلى المركـبـ

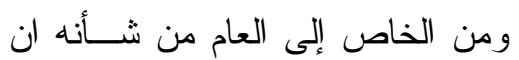

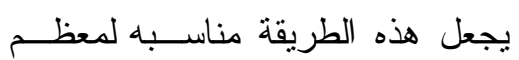

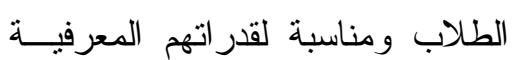

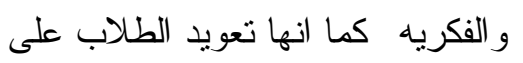
الاعتماد على النفس و اكتثاف الحلول التقنيات الحديثه وتدريس الرياضيات :

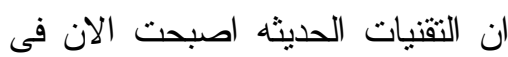
عصر التقدم التكنولوجى الرهيب و التطورات

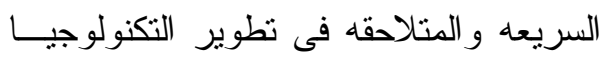

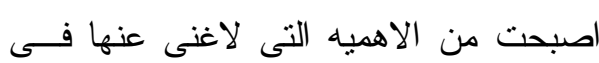

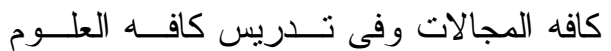
وعلى راسها علم الرياضيات وذللك لان دمج التقنيات الحديثه فى اساليب وطرق التذريس

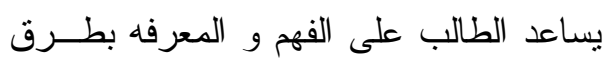

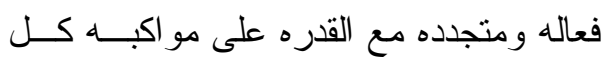
ماهو جديد وحديث علـى مـستوى الكــره الارضيه وللتقنيات الحديثه اهميه كبرى فـى فئى

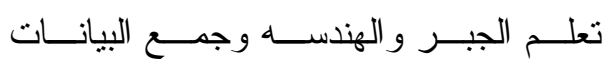

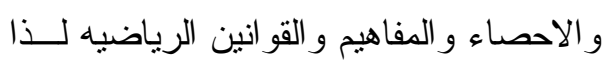
للمسائل الرياضيه بأنفسهم . (') 
تــــريس الرياضــيات بالتقنيــات و الطــرق التكنولوجيه الحديثه وعدم مقـدرتهم علــى تشجيع الطالب على التفاعل بصوره ايجاييــــ

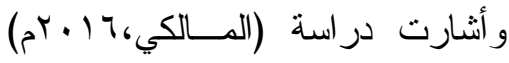

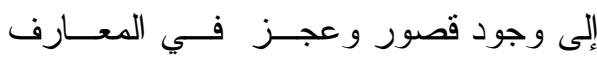

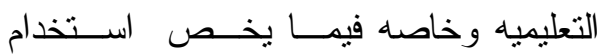

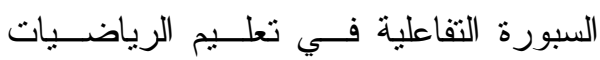

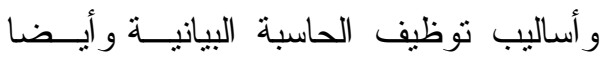
نقص في تو افر التقنيات الحديثـــة والبـــر امج

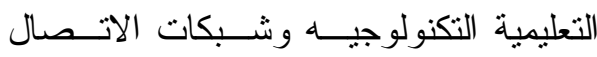
والانترنت داخل فصول الدر اسة. (£) التوجهــات الحديثــهـ فــــ تعلــيم وتعلـــم

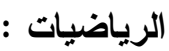

اولا : الرياضيات المجتمعيه : وقد تم تعريفها بانها الرياضيات التى تدخل فى جميــع جو انــب حيــاه الطالــبـ

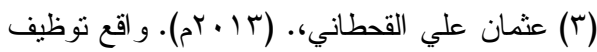
المستحدثات التكنولوجية في تدريس رياضــيات

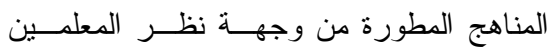
و المشرفين التربويين بمنطقة تبــوك التعليميــة.، المجلة التربوية الدولية الدتخصصة، الأردن

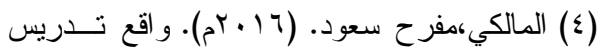
الرياضيات في ضوء مطالب التقنية لمقــررات المرحلة الثانوية، مجلة تربويـات الرياضــيات
5- Comic maker ،Sock puppets ، Texting story

تطبيق صمم لانــشاء القــصص و المفـــاهيم الرياضيه بطريقه كرتونيه.

وتعتمد فاعلية ونجاح هـــهـ التقنيــات

على قيام المعلم بمر اقبه مخرجــات الــتلعم و التخطيط و التتظيم الجيد له مع اختيار التقتيه

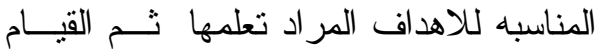

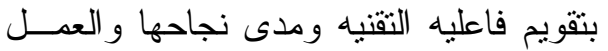

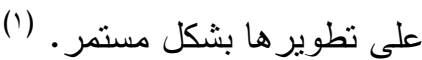
و هناك العديد من الدر اسات التى نتاولت هذا الموضوع منها : در اســـه (Gunbas,2012) و التــى اكدت نتائجها الى انه حدث تحسن ملحــوظ فى مستوى التحصيل الدراسى عند الطــلاب عند استخدام طريقه التقنيات الحديثه. (r)

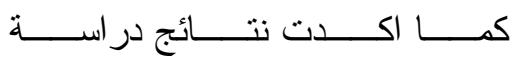

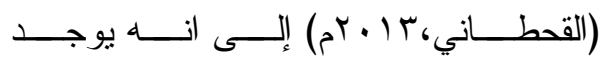
قصورو اضح فى أداء معلمي الرياضيات عند (1) نائل جو اد الناطور ، (1) (Y)، اساليب تـدريس الرياضـــات المعاصــــهـ ، دار غيــــاء للنــشر

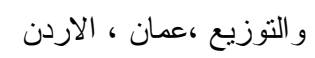

( $५$ ) Gunbas,Nilgun.(2012). The Effect of A computer Based story on 6th Grade students Mathematics word Problem sloving Achievement Doctor of Education.Columbia University 
وبالتالى التفكير فى ايجاد حلول لها مما ينمى

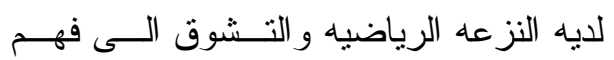
ودر اسه الرياضيات . (־)

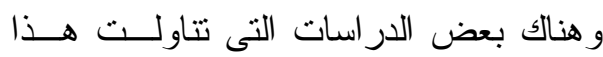
الاتجاه مثل در اسه (Gutierrez, 2013; فو ائد متعدده لهذه التوجهات الحديثه ومن هذه دراه الفو ائد و التى اكدت فى نتائجها الى وجود لـون 1. نساعد على زياده وتحسين مسستوى

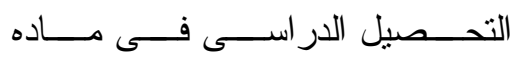
الرياضيات بالنسبه للطالب

r. تتمى لدى الطالب مهـــارات التفكيــر

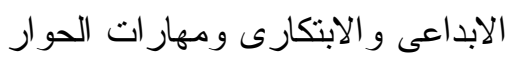

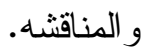

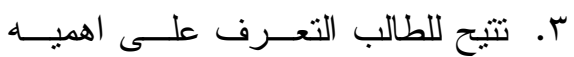
در اسه وقهم الرياضيات.

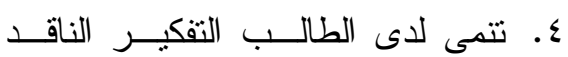

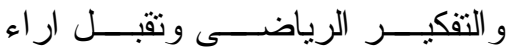
الآخرين.

ويمكن توظيف توجه الرياضيات المجتمعيه فى الفصل الاراسى عن طريق :

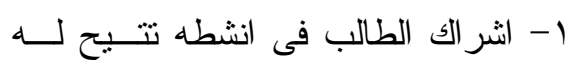

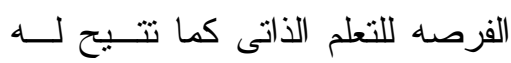

(r) Rosa, M. \& Orey, D. C. (2011). Ethnomathematics: the cultural aspects of mathematics. Revista Latinoamericana de Etnomatemática, $4(2)$

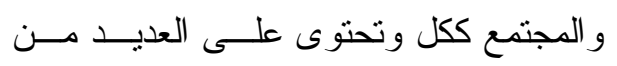

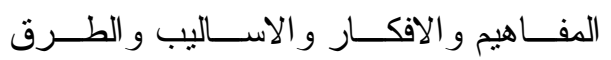
الرياضيه التى لاغنى عنها فى الحياه اليوميه

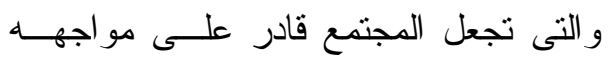

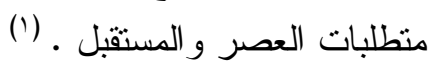

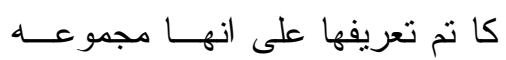

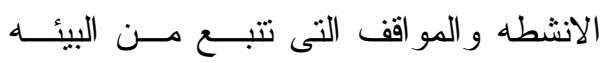

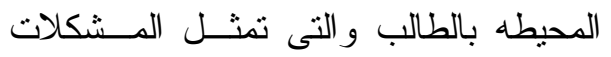
و المعوقات الموجوده داخل هذه البيئه مع قيام

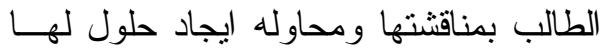

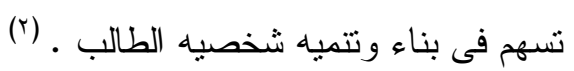
ان الرياضيات المجتمعيه من ضــــن لهن التوجهات الحديثه و المهمه الموجوده الان فى لرئي

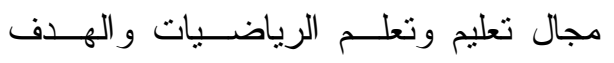

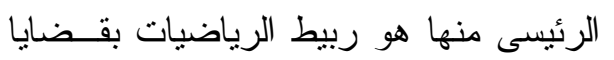

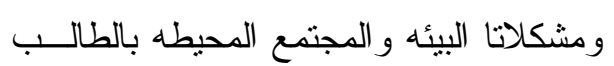
فعن طريق تدريس هذه الرياضيات يمكن ان

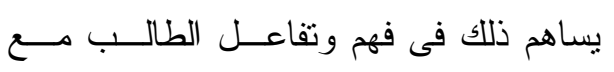

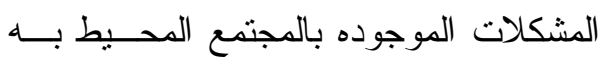

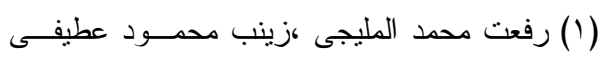

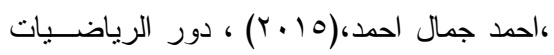

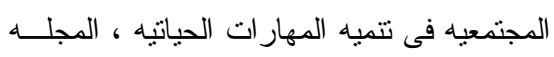
العلميه لكليه التربيه ، جامعه اسيوط.

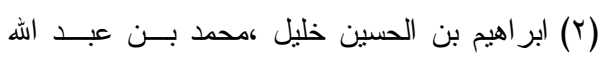

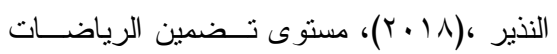

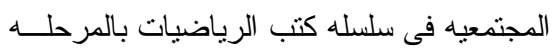

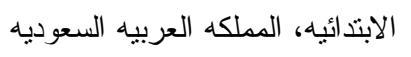


الحوارات الرياضيه التى تتم بــيم الطالــب

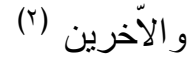

كما نم تعريفها ايضا على انها القره

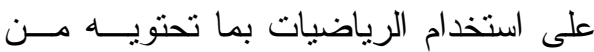

رموز ومعادلات للتعبير عن موقف رياضى لرئ

معين ويتم ذلك عن طريق ربطها بالافكـار

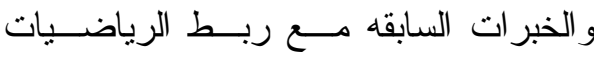

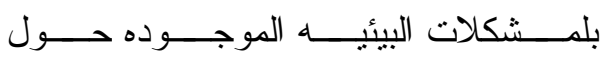

(ץ) الطالب (ب)

ان القوه الرياضيه تتضنمن اسـتطاعه

الطالب التفكير وحل المشكلات و الاســتـلال ويتم ذلك من خلال معرفــه وفهـم طبيعـهـ

الرياضيات وفائدتها وقو انينها و هــــا يمكـن

الطالب من توظيف هذه المفاهيم و المعسارف

فى التعبير عن الافكار الرياضيه وممارســــ

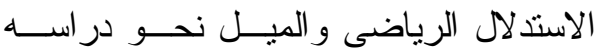

الرياضيات مع ادر الك التداخل الذى ينت بــين

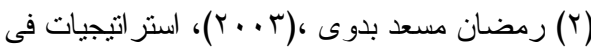

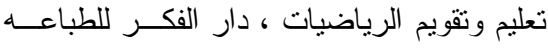

و النشر و التوزيع ،عمان ،الاردن التريات ،ارن

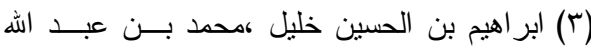

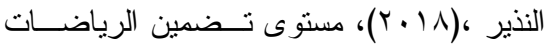

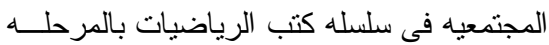

الابتدائيه، المملكه العربيه السعوديه

$$
\begin{aligned}
& \text { حريـــهـ اتخــــاذ القـــر ارات وتحمــلـل }
\end{aligned}
$$

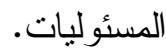

r- اثشر الك الطالب فى انشطه تعتمد علـى

علم الرياضيات و اتاحه الفرصـــهـ لــهـ

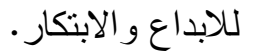

r- اتاحه الفرصــه للطالــب لاســتخدام

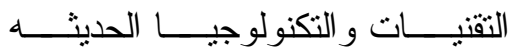

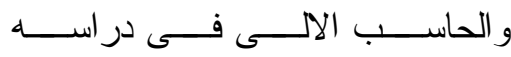

$$
\text { الرياضيات. }
$$

ع- اشر الك الطالب فى انـشطه مرتبطــهـ

بالمجتمع المحيط به على ان تتتضمن

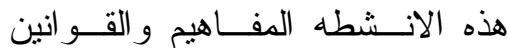

و النظريات الرياضيه ـ (1)

ثانيا: القوه الرياضيه :

وتعرف القوه الرياضيه علــى انهــا

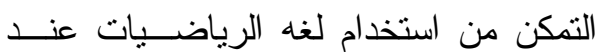

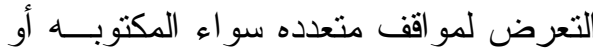

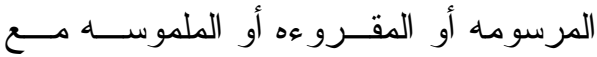

تقسير وفهم هذه المواقف من خلال استخدام

(')Gutiérrez, R. (2013)" Building "Consciousness and Legacies": Integrating Community, Critical, and Classical Knowledge Bases in a Precalculus Class", doctoral degree for university of Arizona, USA. 
وللبر اعه الرياضيه ه مكونات رئيسيه :

$$
\begin{aligned}
& \text { 1- الاستيعاب المفاهيمى. } \\
& \text { r- الطلاقه الاجر ائيه . } \\
& \text { r- الاستدلال و التفكير . } \\
& \text { ع- الكفاءه الاستر اتيجيه . } \\
& \text { 0- الرغبه المنتجه. }
\end{aligned}
$$

فو ائد البراعه الرياضيه بالنسبه للطالب:

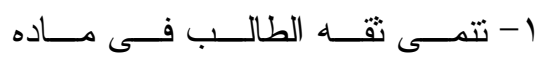

الرياضيات مع الاحتفاظ بما تعلمه منها.

r- تعمل على زياده التحصيل الدراسى

$$
\text { وتتمى التفكير الرياضى السليم. }
$$

ب- تشعر الطالب بأهميـــه الرياضـــيات

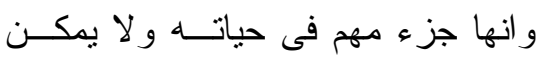

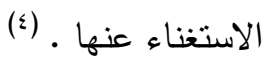

$$
\begin{aligned}
& \text { ممارسـات تلريسيه مقترحسه فــى ضـــوه } \\
& \text { مهرات القرن الواح و العشرين فى تــدريس } \\
& \text { الرياضيات }
\end{aligned}
$$

1 - القيام بتوزيع الطلاب على مجموعات

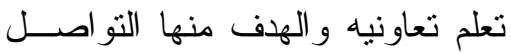

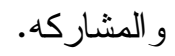

(4) Kisker , E Eliason.(2012) "The Potential of a Culturally Based Supplemental Mathematics Curriculum to Improve the Mathematics Performance of Alaska Native and Other Students" Journal for Research in Mathematics Education.

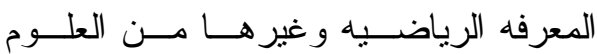

$$
\begin{aligned}
& \text { الآخرى. (') } \\
& \text { ثالثا : البراعه الرياضيه : } \\
& \text { يـشير المجلــس القــومى للبحــوث } \\
& \text { بالو لايات المتحده الامريكيه الى ان النجــاح } \\
& \text { فى تعلم الرياضيات قد مسـر بالعديــــــــن }
\end{aligned}
$$

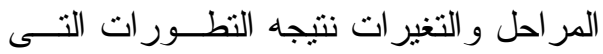

$$
\begin{aligned}
& \text { حدثت خلال الفتز ات السابقه مــــا ادى الــى لـى } \\
& \text { ظهور ما يسمى بالبر اعه الرياضيه وقد ظهر }
\end{aligned}
$$

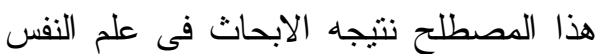

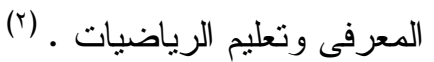

(1) Shannon ,E. ( 2015)"Achievement and 21st century skills in Elementary school students", PhD Thesis , Dowling College, Oakdale, NY, USA.

(2) Groves ,S. ( 2012)."Developing Mathematical Proficiency", Journal of Science and Mathematics Education in Southeast Asia, Vol. 35 No. 2

(3) Freund, D. ( 2011)." Opportunities to Develop Mathematical Proficiency: How Teachers Structure Participation in the Elementary Mathematics Classroom", the degree Doctor of Philosophy in Education, University of California, Los Angeles, USA. 
ب- الأهميه الو اضحه لفهم ابسط المفــاهيم

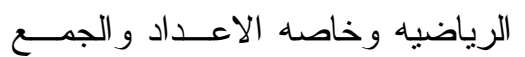

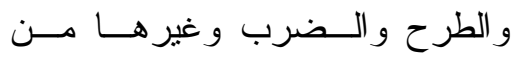

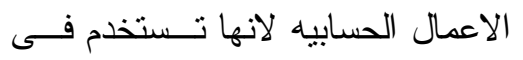

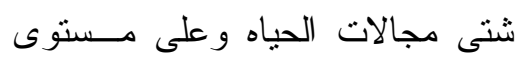

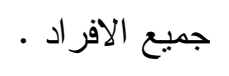

ـ - الـــنقص الو اضــــح فــى الامكانيــات

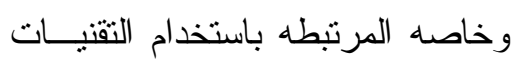

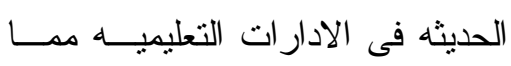

يؤثز على الطالب ويسبب لـــه عـــدم

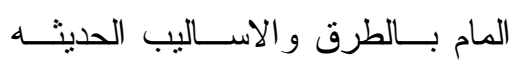

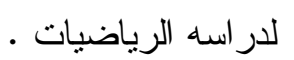

0- العجز فى وجود معلم رياضيات على

مستوى اكاديمى وتقنى يؤ هله للتعامل

من التقنيات الحديثه فى تدريسه لماده

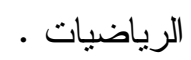

؟- عدم وجود الدر اسات الكافيه التى تهنم

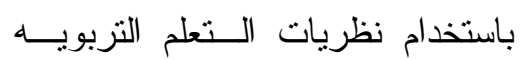

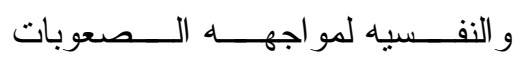

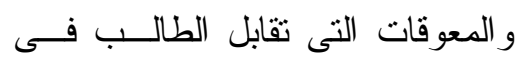

$$
\text { در استه للارياضيات. }
$$

V- عدم وعى المعلم بتأثنير الفروق الفرديه

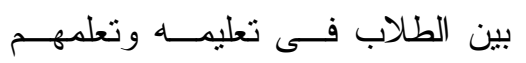

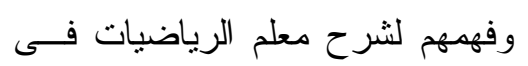

$$
\text { الحصده الار اسيه. }
$$

Y- العمل على التوســع فــى اســتخدام

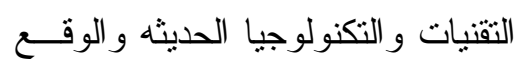

الافتر اضى ونظريات التعلم النفـسيه ولنيه

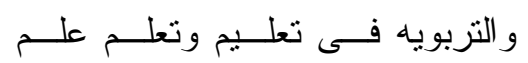

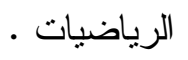

r- العمل على ان تتيح منــاهج ومـــو اد

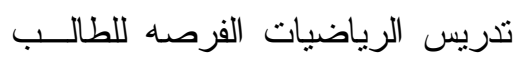

للتفكير الابداعى و الابتكارى و التفكير

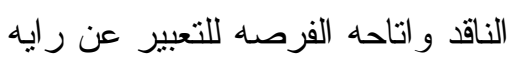

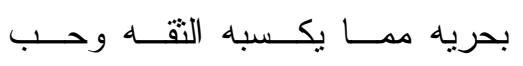

الرياضيات و الاقبال على تعلمها. (')

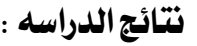

1- من خلال الدراسه السابقه اتضـح لنـــا

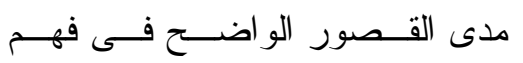

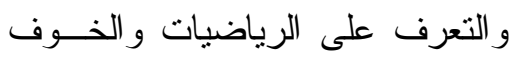

من در استها بالنسبه للطـــلاب بــشكل

$$
\text { عام }
$$

ץ- عدم الاهتمام من جانــب الاســره أو

المجتمع بمحاوله ايجاد وتطبيق طرق هن الهن

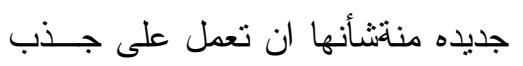

$$
\text { الطالب نحو در اسه الرياضيات. }
$$

(1) Queensland Curriculum and Assessment Authority(QCAA). ( 2015). 21st century skills for senior education, An analysis of educational trends. 


$$
\begin{aligned}
& \text { اعطائهم الفرصــهـه لاتخــاذ القــرار } \\
& \text { 1- على الادار ات التعليميه و القائمين على اتحمل المسئوليات. }
\end{aligned}
$$

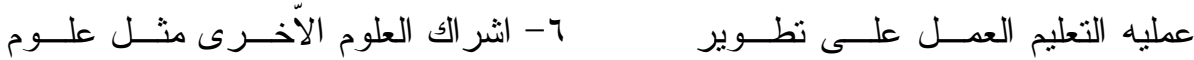

$$
\begin{aligned}
& \text { التزبيه وعلم الــفس مـــع اســتخدام }
\end{aligned}
$$

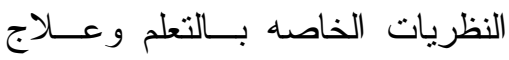

$$
\begin{aligned}
& \text { صعوبات التعلم لمواجهه المعوقـات وتهات }
\end{aligned}
$$

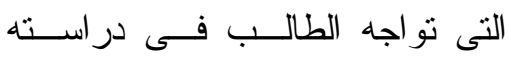

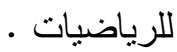

$$
\begin{aligned}
& \text { V- الاكثار من الابحاث و الدر اسات حول } \\
& \text { مشاكل التعلم بشكل عام و الرياضيات }
\end{aligned}
$$

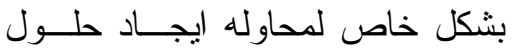

$$
\begin{aligned}
& \text { للصعوبات التى تو اجه عمليه التعلم. }
\end{aligned}
$$

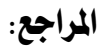

$$
\begin{aligned}
& \text { 1- وليم عبيد، و آخرون.(ع } 9 \text { (1) ، تربويات }
\end{aligned}
$$

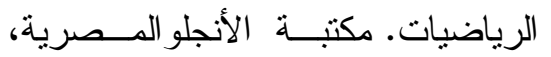

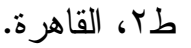

$$
\begin{aligned}
& \text { Y- مجــدي عزيــز ابــــر اهيم،.(9199 ام). }
\end{aligned}
$$

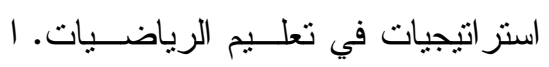

$$
\begin{aligned}
& \text { مكتبة النهضة المصرية ،القاهرة. } \\
& \text { r- محبات أبو عميره ،( . . (Y)،المتفوقون }
\end{aligned}
$$

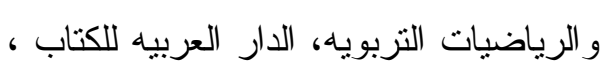

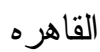

$$
\begin{aligned}
& \text { 4-Bassarear, T., (2001): } \\
& \text { Mathematics for Elementary } \\
& \text { School Teachers, Keene State } \\
& \text { المناهج التعليميه وخاصــه بالنـسبه }
\end{aligned}
$$

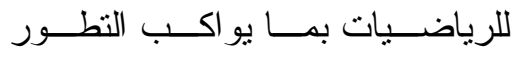

$$
\begin{aligned}
& \text { التكنولوجى و التقنى الذى يحدث فـى لـى }
\end{aligned}
$$

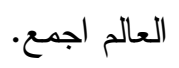

$$
\begin{aligned}
& \text { r- العمل على ربط الرياضيات بالمجتمع } \\
& \text { الذى يعيش فيه الطالــبـ ومـــكلاته } \\
& \text { لاشر الك الطالب فى هذه المــشكلات }
\end{aligned}
$$

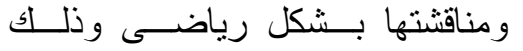

$$
\begin{aligned}
& \text { باستخدام اسلوب الرياضات المجتمعيه }
\end{aligned}
$$

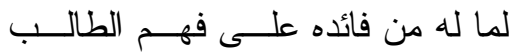

$$
\begin{aligned}
& \text { وتعريفه باهميه در اسه الرياضيات. } \\
& \text { r- القيام بتدريب الكوادر الواعـده مــن }
\end{aligned}
$$

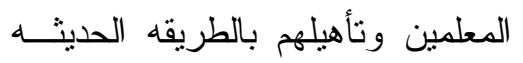

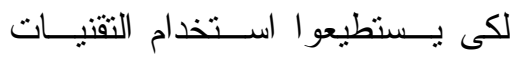

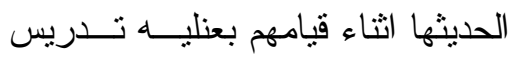

$$
\begin{aligned}
& \text { الرياضيات } \\
& \text { ع- توفير الدعم المــالى الــلازم لاقتتـــاء }
\end{aligned}
$$

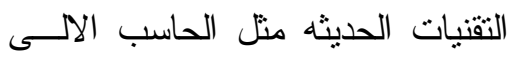

$$
\begin{aligned}
& \text { و السبوره التفاعليه وتوفير استخدامها } \\
& \text { للطلاب عند در استهم للرياضيات. } \\
& \text { 0- تشجيع الطلاب على الابتكار و الابداع } \\
& \text { والتعبير بحريه عــن افكـار هم مــع الفع }
\end{aligned}
$$




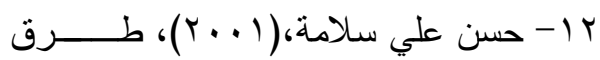

تدريس الرياضيات بين النظرية

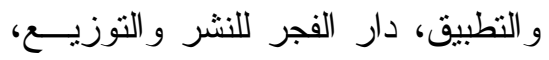

القاهره

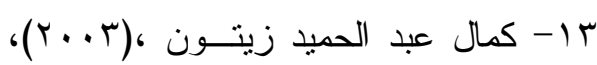

التدريس نماذجه ومهار اته ، عالم الكتب كئب

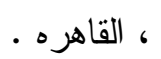

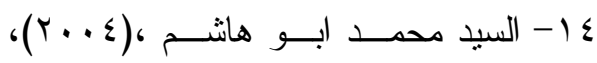

اسلوب حل المشكلات فى التعلم ،كليــــ التربيه ، جامعه الزقازيق.

10- توفيق احمد مرعى ومحمــــ محمــود

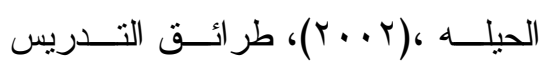

العامه،دار المسيره ، عمان ، الاردن.

1 - نائل جو اد الناطور ،(11)، ـ اساليب

تدريس الرياضــيات المعاصــره ، دار

غيداء للنشر و التوزيع ،عمان ، الاردن.

17- Gunbas,Nilgun.(2012).The

Effect of A computer Based story on 6th Grade students

Mathematics word Problem sloving Achievement Doctor of

Education.Columbia

University.

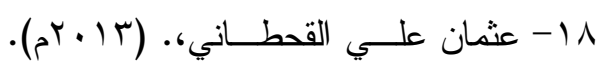

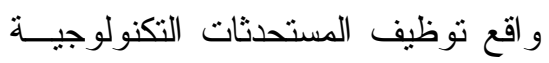

في تدريس رياضيات المناهج المطــورة
College Boston, Second

Edition, New York.

0- اسماعيل محمـــ الـصـادق، (Y... (Y)،

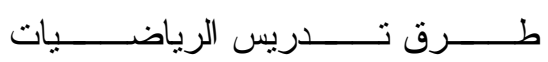

نظريــات وتطبيقات،دار الفكر العربــى لريّى

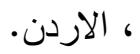

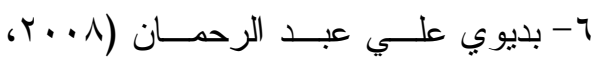

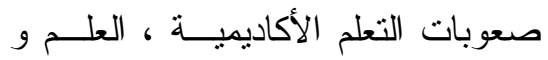

الإيمان للنشر و التوزيع ، الإسكندرية.

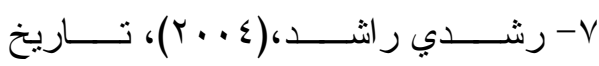

الرياضيات العربية بين الجبر و الحساب،

مركز در اسات الوحدة العربية

ᄉ- محمد أمين المفتي ،(990 ()، قــــراءات

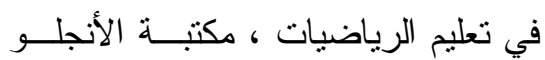

المصرية ، القاهرة .

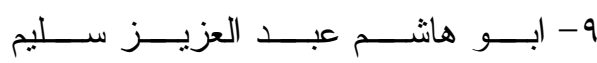

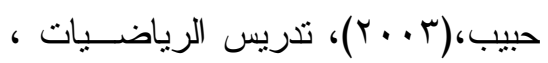

مكتبه النهضه المصريه ،القاهره.

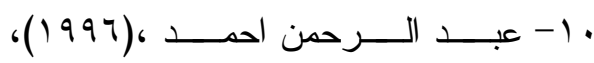

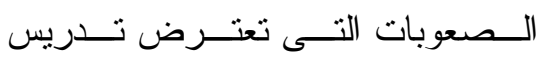

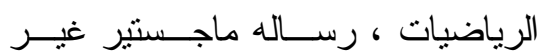

منشوره ، كليه التزبيه ، جامعه بنها.

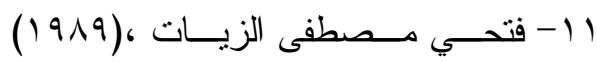

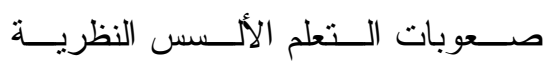

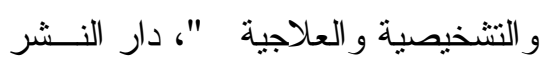

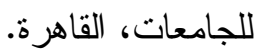


Critical, and Classical من وجهة نظر المعلمـين والمـشرفين

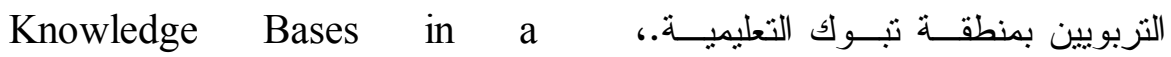

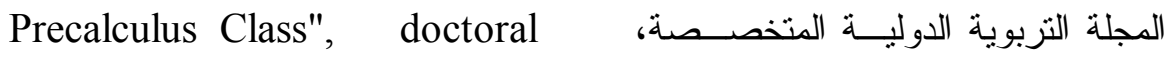

degree for university of الأردن.

Arizona, USA.

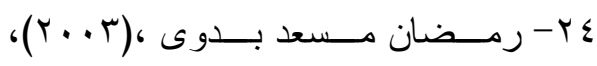

19 - المالكي،مفرح سعود. (7 19

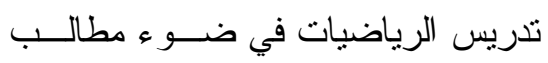

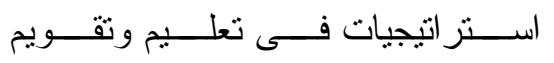

الرياضيات ، دار الفكر للطباعه و النشر لئر ولئر

التقنية لمقررات المرحلة الثانوية، مجلة و التوزيع ،عمان ،الاردن.

تربويات الرياضيات ،مصر .

•r-رفعت محمد المليجى ،زينب محمــود

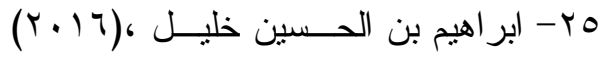

عطيفى ،احمد جمال احمـد،(10 ب) ،

الممارسات التدريسية لمعلمي رياضيات

دور الرياضيات المجتمعيه فــى تتميــهـ

الصفوف العليــا فــى مكونــات القــوه

الرياضيه ، رساله التزبيه وعلم الــنفس

المهار ات الحياتيه ، المجله العلميه لكليه التزبيه ، جامعه اسيوط.،

،جامعه الملك سعود، المملكه العربيــهـ

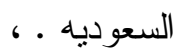

اب - ابر اهيم بن الحسين خليل ،محمـــــــن

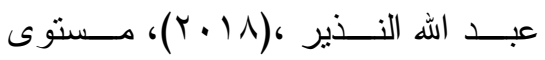

26- Shannon ,E. (2015)

تضمين الرياضات المجتمعيه فى سلسله

"Achievement and 21st century skills in Elementary school

كتب الرياضيات بالمرحلــــه الابتدائيــه، المملكه العربيه السعوديه.

students", $\mathrm{PhD}$ Thesis,

Dowling College, Oakdale, NY, USA.

27-Groves ,S. ( 2012)."Developing

Mathematical Proficiency",

Journal of Science and

Mathematics Education in

Southeast Asia, Vol. 35 No.2

22-Rosa, M. \& Orey, D. C. (2011).

Ethnomathematics: the cultural aspects of mathematics.

Revista Latinoamericana de

Etnomatemática, 4(2)

23-Gutiérrez, R.(2013)"Building

"Consciousness and Legacies":

Integrating Community, 


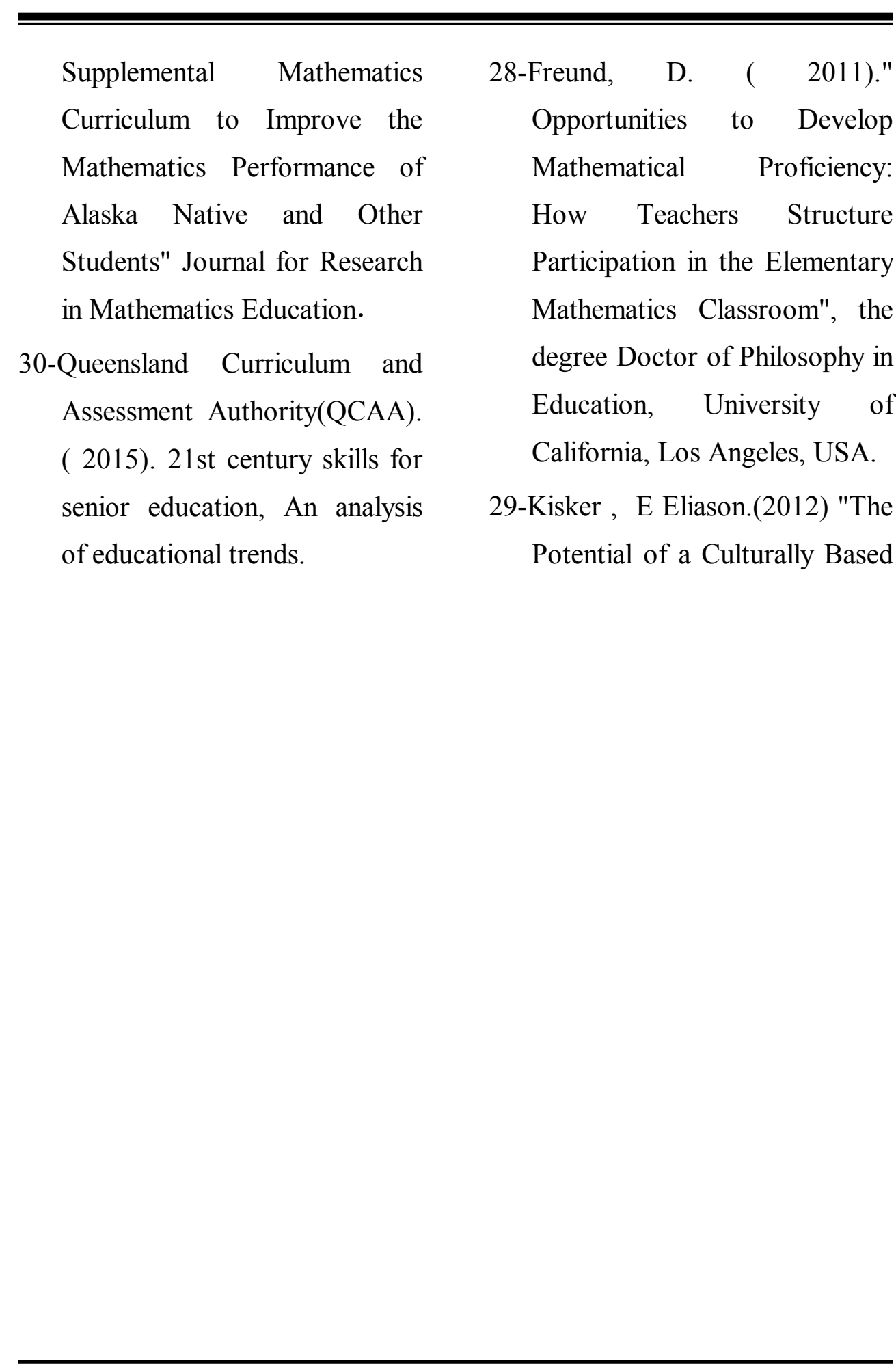

